\title{
Improving the stability of high embankment slopes on weak foundations
}

\author{
Aleksey Kamenchukov ${ }^{1, *}$, Ilya Ukrainskiy $^{1}$, and Gamilia Nikolaeva ${ }^{2}$ \\ ${ }^{1}$ Pacific National University, Tikhookeanskaya St. 136, Khabarovsk, 680035, Russia \\ ${ }^{2}$ North-Eastern Federal University, Belinsky St. 58, Yakutsk, 677000, Russia
}

\begin{abstract}
The article considers the issues of assessing the stability of nonstandard soil-geological systems in difficult conditions. An analytical review of modern methods and tools for assessing the stability of embankment slopes is carried out. The features of the work of the embankment in the areas of the spread of permafrost are considered. The features of the design of embankments on permafrost soils with the preservation or partial thawing of frozen soils have been studied. Two versions of the calculated static schemes of sliding surfaces are presented: base - subgrade and base - subgrade - pavement. Based on the results of field studies, the physical and mechanical characteristics of the soils of the embankment and the base of the subgrade were determined, which became the basis for mathematical modeling and assessment of the stability of the embankment slopes. In software packages GeoStab and Geo5, based on the finite element method and the results of field studies, digital models of embankments were built on a weak foundation. The calculation of the stability of the system "base - subgrade" under the action of a standard uniformly distributed load has been performed. Two models of the system and the base - subgrade - road surface are considered: without cracks on the rolling strip and with cracks. It was found that coating defects affect the stability of the system only in the presence of an earthquake of medium strength and more. Recommendations for strengthening the slopes of embankments operating in difficult soil-geological conditions are given.
\end{abstract}

\section{Introduction}

The assessment of the bearing capacity of base and slopes is an important scientific and technical task of the design of roads and protective engineering structures. The stability of soil slopes and embankments of the subgrade depends on the physical and mechanical properties of materials, which can change under the influence of many natural and technological factors: rainfall intensity, moisture content of material, seismic activity, static load (weight of the embankment and standing vehicles), uneven dynamic impact of transport load, level of solar radiation and other factors [1 -3].

At present time this area of soil mechanics has well developed in the field of theory and mathematical modeling [4 - 8]. However, a number of fundamental issues remain, which

\footnotetext{
*Corresponding author: 006641@pnu.edu.ru
} 
are necessary to solve for the further development of the theory of stability and the improvement of practical methods for calculating the bearing capacity of soil body [9 - 12].

One of these problems is ensuring the reliability of the system «subgrade - pavement» on a thawing base. The relevance of this problem is beyond any doubt both in the design of new roads and in the operation and reconstruction of existing roads on permafrost soils. This direction in construction is important because most of Russia is located in the territory of permafrost soils, and issues such as traffic safety, expansion of the network of roads and railways, development of new territories in difficult geocryological conditions are an important strategic task of the government.

\section{Materials and methods}

\subsection{Special problems of the stability of slope}

The roads on permafrost soils are unique engineering structures operating in difficult climatic conditions, therefore, all typical design solutions must be adapted to specific conditions of the terrain. Unacceptable deformations occur in the engineering structures constructed on permafrost soils without the adoption of special means and technologies, which lead to rapid destruction or to the occurrence of emergency conditions $[6,13,14]$.

As is known from the experience of domestic and foreign studies, permafrost soils have rigid internal ice-cement bonds, which are sufficiently strong natural formations while maintaining a negative temperature of soil [15].

However, with the accumulation of positive air and soil temperatures, the structural icecement bonds quickly collapse, the soil becomes waterlogged with melt water and turns into a liquefied soil that is unable to bear and adequately redistribute the load from the structures, which lead to thermal subsidence of former permafrost soils (thermokarst).

The following principles are followed when designing the subgrade on permafrost soils:

Preservation of permafrost soils at the base of the subgrade during the entire period of road operation (the design state of the base soil is frozen). The design is carried out in areas that are particularly difficult in terms of permafrost soil conditions (3rd type of terrain) with low-temperature permafrost on clayey highly subsiding soils with a moisture content above the liquid limit. Thawing of the base soil is not allowed, as it can lead to unacceptable deformations of the subgrade and destruction of the pavement. The subgrade is constructed in embankments of unconsolidated coarse soils with the obligatory preservation of undisturbed vegetation cover at the base of the embankment and along the road lane.

Partial thawing of frozen soils by an amount that ensures the stability of the subgrade, considering the permissible subsidence of the pavement (the design state of the base soil is frozen). The design is carried out in areas that are difficult in terms of permafrost soil conditions (2nd type of terrain) with low-temperature permafrost. When designing roads based on the principle of limiting the depth of thawing of base soils, based on permissible deformations, the subgrade is designed in accordance with cross sections. It is allowed to construct a subgrade from local clay soils with the laying of concentrated or road-side borrow pit. In this case, it is forbidden to remove or destroy the vegetation cover at the base of the embankment.

As the analysis shows, one of the reasons for the deformations of the slopes of the subgrade are design errors caused by the use of calculation methods that do not fully consider the peculiarities of the processes of thermal and mechanical interaction of the subgrade and the thawing base $[16,17]$.

The assessment of the stability of slopes and surfaces is carried out by the method of calculating circular sliding surfaces $[1,2,18,19]$. All methods of limiting equilibrium 
assume that the soil body above the sliding surface is divided into blocks (dividing planes between blocks are always vertical). The blocks are acted upon by compressive (E) and normal $(\boldsymbol{X})$ forces arising between the blocks, shear $(\boldsymbol{N})$ and normal $(\boldsymbol{T})$ forces arising inside the block, as well as the weight of the soil $(\boldsymbol{W})$ inside the block. The principal scheme of assessing the stability of the embankment slope is shown in Figure 1.

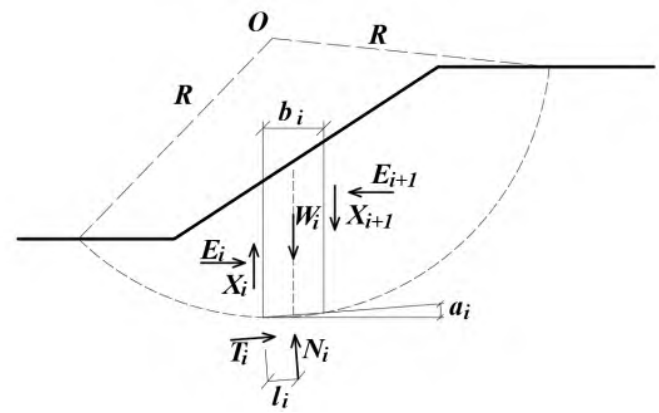

Fig. 1. Static scheme of section of the sliding surface.

Scheme 1 considers only the load from the own weight of the embankment of the subgrade and does not consider the effect of the static or dynamic load (F) from the vehicle. Also, the scheme is presented for a homogeneous soil body, which in real conditions also does not correspond to reality. In addition, the condition of the subgrade soil and pavement materials of the operating roads is heterogeneous. Often in the upper layers of the pavement and the base of the pavement there are defects and deformations, for example, cracks, which do not allow considering the upper layer of the structure as an infinite half-space, dividing it into several elements that have only a very conditional (not rigid) connection with each other along the adjacent border. The modernized scheme of the system «base subgrade - pavement» is shown in Figure 2.

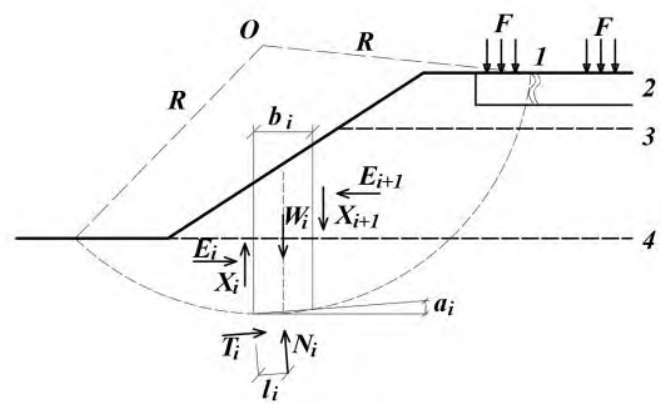

1 - crack in the pavement; 2 - pavement; 3 - border of the bottom of the base of the pavement; 4 border of the base of the subgrade.

Fig. 2. Real scheme of section of the sliding surface under static loading of the system «base subgrade - road pavement»).

It is necessary to solve the problem of assessing the long-term stability and stress-strain behavior of the subgrade, both during the construction of new roads and during the reconstruction of the existing subgrade, in order to reduce the number and extent of deformations. At the same time, a mechanism should be developed in the calculation methodology that will allow modeling the stress-strain state of the system «subgrade pavement», based on the soil body, in order to assess the stability and stress-strain behavior of the structure, considering not only the consolidation processes occurring in the thawing base, but also the features of the distribution of the transport load in a structure with surface or internal deformations. 


\subsection{Methodology for obtaining initial data for a mathematical model}

The calculation of the stability of the embankment refers to ultimate limit state. Therefore, stability is determined by the stress-strain state and strength of the embankment soils. The three-dimensional stress state of the soil body is characterized by strength and physical and mechanical characteristics - deformation modulus, specific gravity, specific cohesion and angle of internal friction [2, 10, 20, 21].

The reasons leading to the loss of the stability of soil body in slopes are the following:

- heaving of slope due to soil moistening, i.e. a decrease in the specific cohesion $\mathrm{c}$ and the angle of internal friction $(\varphi)$ and increase in the specific gravity $(\gamma)$;

- increase in the steepness of the slopes;

- increase in the load on the embankment;

- decrease in the strength characteristics of soil of the slope body due to moistening by surface water and groundwater or other circumstances;

- seismic or dynamic loading.

Soil density affects the strength and stability of soils with simultaneous effects of loads, weather and climatic factors on them. There are minimum values of density, which ensure satisfactory stability of soil in relation to the type of engineering structure constructed on it $[6,10,13]$. These minimum values depend on climatic conditions, type of terrain, location of the soil layer in the embankment, temperature and humidity conditions of the environment and soil moisture [22].

Table 1. Determination of physical and mechanical properties of soil.

\begin{tabular}{|c|l|c|c|}
\hline № & \multicolumn{1}{|c|}{$\begin{array}{c}\text { Soil type according to GOST 25100 } \\
\text { (National State Standard) }\end{array}$} & $\begin{array}{c}\text { Optimum } \\
\text { moisture content, } \\
\%\end{array}$ & $\begin{array}{c}\text { Full density, } \\
\mathrm{kg} / \mathrm{m} 3\end{array}$ \\
\hline Soil №1 & Soft sandy loam & 12.46 & 2.05 \\
\hline Soil №2 & Sand gravel mix & 12.10 & 2.14 \\
\hline Soil №3 & Fine sand & 11.49 & 2.06 \\
\hline Soil №4 & Fine sand & 12.66 & 2.35 \\
\hline
\end{tabular}

Table 2. The results of the study of the grain composition and soil types.

\begin{tabular}{|c|c|c|c|c|c|c|c|c|c|}
\hline \multirow{2}{*}{$\begin{array}{c}\text { Sample } \\
\text { name }\end{array}$} & \multicolumn{7}{|c|}{ Grain composition, \%, particle size, mm } & $\begin{array}{c}\text { Soil type according } \\
\text { to GOST 25100-95 }\end{array}$ \\
\hline Soil №1 & 0.3 & 0.67 & 44.92 & 0.64 & 8.51 & 0.42 & 36.35 & 8.19 & Soft sandy loam \\
\hline Soil №2 & 20.68 & 3.78 & 6.54 & 1.89 & 5.99 & 30.87 & 24.69 & 5.56 & $\begin{array}{c}\text { Mixture of crushed } \\
\text { stone, fine sand and } \\
\text { crushed brick }\end{array}$ \\
\hline Soil №3 & 0.32 & 2.40 & 2.49 & 6.68 & 9.11 & 47.36 & 25.69 & 5.95 & Fine sand \\
\hline Soil №4 & 0 & 0.04 & 0.01 & 0.28 & 0.96 & 49.51 & 42.32 & 5.19 & Fine sand \\
\hline
\end{tabular}

The reconnaissance survey of the highway «Vilyui» at the $1015-1035 \mathrm{~km}$ section was carried out in order to identify the design and operational features of the system «base subgrade - pavement», clarify the engineering, geological and hydrological conditions and determine the nature of permafrost soils of the road base. Clarification of geological and hydrological conditions was carried out by boreholes, with the following determination of moisture content and type of soil in the laboratory of the Department of Roads and Airfields of the M. K. Ammosov North-Eastern Federal University.

The soils for the study were selected within the depth of the seasonally thawed layer. The physical properties of the soils were determined during these studies in order to establish the pattern of the stability of the slopes of the embankment. The results of studies of the grain composition and physical properties of soils are presented in tables 1 and 2 . 


\section{Results}

\subsection{Mathematical modelling of the system «base - subgrade»}

Theoretical research and numerical modeling were carried out to solve the set tasks. In order to develop a technique for assessing the stability of embankment slopes, a study was carried out by numerical modeling of the stress-strain state process by the finite element method using GeoStab (demo) and Geo5 (educational license) software packages which use the finite element method and the results of experimental studies.

An embankment with slope angle $\alpha=36^{\circ}$, load $P=5 \mathrm{kN} / \mathrm{m}^{2}$ and soils with the characteristics given in Table 3 was used as a design model. All calculations were carried out by a numerical method in the Geo5 software package. The variation range of the specific gravity of the embankment soil (fine sand) is $\gamma=16.5-18.5 \mathrm{kN} / \mathrm{m}^{3}$ with a step of 1 $\mathrm{kN} / \mathrm{m}^{3}$.

Three series of calculations were carried out to create slide lines and calculate on them the value of the safety factor for the embankment $(\mathrm{h}=5.0 \mathrm{~m}, \mathrm{~b}=10 \mathrm{~m}$, slope $1: \mathrm{m}=1: 1.5$, $\mathrm{R}=14.16 \mathrm{~m})$.

Table 3. Physical and mechanical characteristics of soils.

\begin{tabular}{|c|c|c|c|c|}
\hline Soil type & $\begin{array}{c}\text { Specific gravity } \\
\text { of soil at natural } \\
\text { moisture, } \gamma, \\
\mathrm{kN} / \mathrm{m}^{3}\end{array}$ & $\begin{array}{c}\text { Specific } \\
\text { cohesion of soil } \\
\text { at natural } \\
\text { moisture, } \mathrm{s}, \mathrm{kPa}\end{array}$ & $\begin{array}{c}\text { Angle of } \\
\text { internal friction } \\
\text { at natural } \\
\text { moisture, } \varphi, \\
\text { deg }\end{array}$ & $\begin{array}{c}\text { Specific gravity } \\
\text { of soil at full } \\
\text { water saturation, } \\
\gamma \mathrm{sat}, \mathrm{kN} / \mathrm{m}^{3}\end{array}$ \\
\hline Fine sand & 15.0 & 3.0 & 28.0 & 31.0 \\
\hline Soft sandy loam & 18.0 & 10.0 & 15.0 & 20.3 \\
\hline
\end{tabular}

The radius of the sliding surface is determined by the GeoStab program as critical and equals to $\mathrm{R}=14.16 \mathrm{~m}$. Based on the current design standards, the acceptable coefficient of stability of the embankment slopes $(\boldsymbol{F} \boldsymbol{s})$ is 1.25 . The calculation of the stability of the embankment slope is shown in Figure 3.

Calculation of safety factor by the Morgenstern-Price method, moments:

$$
F S=\Sigma \text { Mreact } i / \Sigma \text { Mact } i
$$

$$
F_{S}=5729,2 / 5844,5=0,980
$$

Calculation of safety factor by the Morgenstern-Price method, forces:

$$
\begin{gathered}
F s=\Sigma F x \text { react } i / \Sigma F x \text { act } I \\
F s=358,0 / 365,2=0,980
\end{gathered}
$$

Since the coefficient of slope stability does not meet the requirements of ODM 218.2.078-2016 (Road industrial methodical document) «Guidelines for the selection of the structure for strengthening the slopes of the road bed of public roads», the program includes methods for strengthening slopes, for example, using anchors to increase the coefficient of slope stability.

Four constant anchors were included in the program in order to obtain the required coefficient of slope stability. The characteristics of the anchors are presented in Table 4, and the results of modeling in the Geo5 program are shown in Figure 4. 


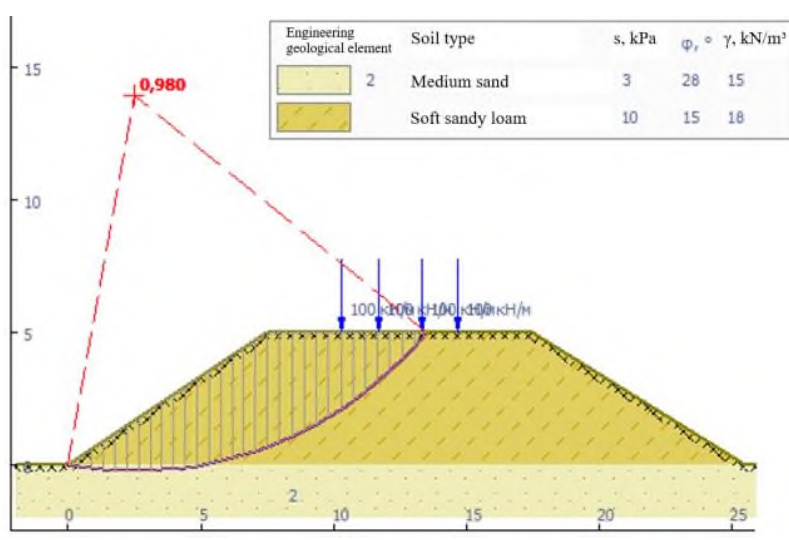

Fig. 3. The results of assessing the stability of the system «base - subgrade» $(\mathrm{h}=5,0 \mathrm{~m}, \mathrm{~b}=10 \mathrm{~m}$, $1: \mathrm{m}=1: 1,5)$ by sequential modeling of its construction.

Table 4. Characteristics of anchors.

\begin{tabular}{|c|c|c|c|c|c|}
\hline № & $\begin{array}{c}\text { Diameter, } \\
\mathrm{mm}\end{array}$ & $\begin{array}{c}\text { Angle of } \\
\text { inclination, deg }\end{array}$ & $\begin{array}{c}\text { Unsupported } \\
\text { length, } \mathrm{m}\end{array}$ & $\begin{array}{c}\text { Anchor } \\
\text { length, } \mathrm{m}\end{array}$ & $\begin{array}{c}\text { Force, } \\
\mathrm{kN}\end{array}$ \\
\hline $1-2$ & 300 & 155 & 2 & 2 & 120 \\
\hline $3-4$ & 300 & 25 & 2 & 2 & 120 \\
\hline
\end{tabular}

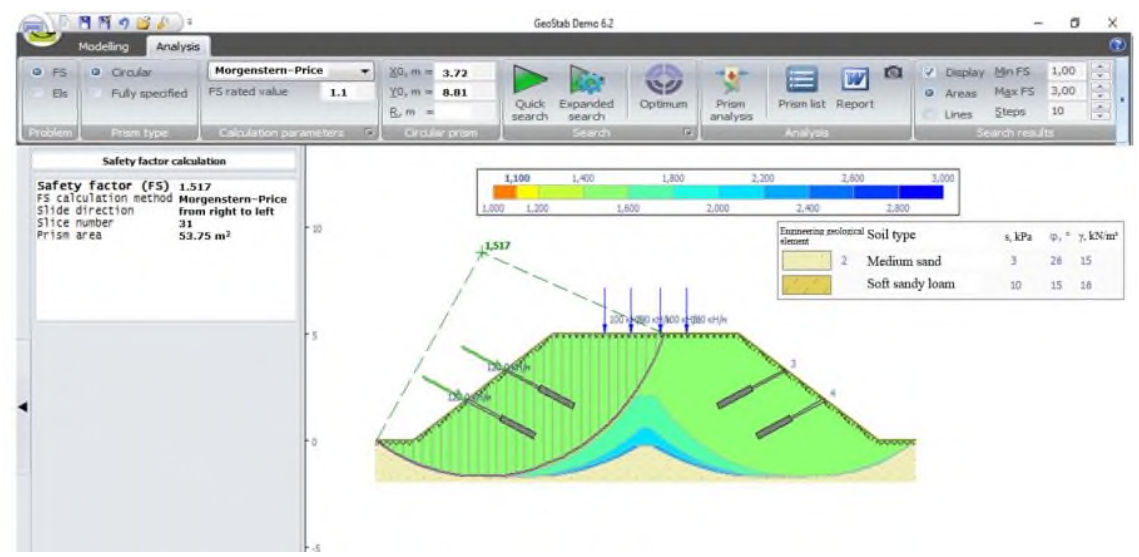

Fig. 4. Location of anchors in the subgrade.

Table 5. Calculated values of the safety factor.

\begin{tabular}{|c|c|c|c|c|}
\hline Soil type & $\begin{array}{c}\text { Specific gravity, } \\
\gamma \mathrm{i} \mathrm{kN} / \mathrm{m}^{3}\end{array}$ & $\begin{array}{c}\text { Safety } \\
\text { factor, Fs }\end{array}$ & $\begin{array}{c}\text { Safety factor using } \\
\text { constant anchors, Fs }\end{array}$ & $\begin{array}{c}\text { Percentage } \\
\text { of change, } \\
\%\end{array}$ \\
\hline Fine sand & 20 & 0.993 & 1.312 & 28 \\
\cline { 2 - 5 } & 17 & 1.012 & 1.454 & 30 \\
\hline \multirow{2}{*}{$\begin{array}{c}\text { Soft sandy } \\
\text { loam }\end{array}$} & 20 & 0.98 & 1.517 & 35 \\
\cline { 2 - 5 } & 17 & 1.024 & 1.598 & 36 \\
\hline
\end{tabular}

As can be seen from Table 5, calculations have shown that the use of permanent anchors as reinforcement increases the safety factor by $28 \%$ in fine sand and by $35 \%$ in soft sandy loam, which meets the requirements of ODM 218.2.078-2016 (Road industrial methodical document) «Guidelines for the selection of the structure for strengthening the slopes of the road bed of public roads». A decrease in the specific gravity leads to an increase in the total 
coefficient of stability by about $1-2 \%$, which does not have a large effect on the overall stability of the embankment soil (Table 6).

Table 6. Calculated values of the safety factor.

\begin{tabular}{|c|c|c|c|c|}
\hline Soil type & $\begin{array}{c}\text { Specific } \\
\text { gravity, } \gamma \mathrm{i} \\
\mathrm{kN} / \mathrm{m}^{3}\end{array}$ & $\begin{array}{c}\text { Safety } \\
\text { factor, } \\
\text { Fs }\end{array}$ & $\begin{array}{c}\text { Safety factor using } \\
\text { geosynthetic material, Fs }\end{array}$ & $\begin{array}{c}\text { Percentage } \\
\text { of change, } \\
\%\end{array}$ \\
\hline \multirow{2}{*}{ Fine sand } & 20 & 1.047 & 1.603 & 53 \\
\cline { 2 - 5 } Silt loam & 17 & 1.098 & 1.685 & 54 \\
\cline { 2 - 5 } & 20 & 1.215 & 1.918 & 57 \\
\hline
\end{tabular}

The coefficient of stability of the reinforced embankment with a decrease in the specific gravity in comparison with the unreinforced embankment increased by $30 \%$. The condition of stability for soft sandy loam and fine sand is not met for both unreinforced and reinforced embankments. Therefore, if the task is to increase the safety factor, it is not recommended to decrease the specific gravity of the soil, since it does not significantly affect $(2 \%)$ the stability of the embankment.

As can be seen from Table 6, calculations have shown that the use of geosynthetic material as reinforcement increases the safety factor by $53 \%$ in fine sand and by $57 \%$ in silt loam. A decrease in the specific gravity leads to an increase in the total coefficient of stability by about $3 \%$, which does not have a large effect on the overall stability of the embankment soil.

The coefficient of stability of the reinforced embankment with a decrease in the specific gravity in comparison with the unreinforced embankment increased by $46 \%$. The condition of stability for silt loam is met for both unreinforced and reinforced embankments, and is not met for silty sand in unreinforced state. Therefore, if the task is to increase the safety factor, it is not recommended to decrease the specific gravity of the soil, since it does not significantly affect (3\%) the stability of the embankment.

\subsection{Mathematical modelling of the system «base - subgrade - pavement»}

The authors put forward and tested the hypothesis that the defects in the pavement (longitudinal cracks) affect the stability of the system «base - subgrade - pavement».

In order to test the hypothesis, the model «base - subgrade - pavement» was supplemented with two equivalent layers of pavement: a base of crushed stone gravel mix $70 \mathrm{~cm}$ thick; asphalt concrete pavement $20 \mathrm{~cm}$ thick. Cracks in the pavement (40 cm deep) are located on the outer track ( $1 \mathrm{~m}$ from the edge of pavement). The characteristics of the layers are presented in Table 7.

Table 7. Physical and mechanical characteristics of materials of equivalent layers of pavement.

\begin{tabular}{|c|c|c|c|c|}
\hline Soil type & $\begin{array}{c}\text { Specific gravity } \\
\text { of soil at natural } \\
\text { moisture, } \gamma, \\
\mathrm{kN} / \mathrm{m}^{3}\end{array}$ & $\begin{array}{c}\text { Specific } \\
\text { cohesion of soil } \\
\text { at natural } \\
\text { moisture, } \mathrm{s}, \mathrm{kPa}\end{array}$ & $\begin{array}{c}\text { Angle of internal } \\
\text { friction at natural } \\
\text { moisture, } \varphi, \mathrm{deg}\end{array}$ & $\begin{array}{c}\text { Specific gravity of } \\
\text { soil at full water } \\
\text { saturation, } \gamma \mathrm{sat}, \\
\mathrm{kN} / \mathrm{m}^{3}\end{array}$ \\
\hline Asphalt concrete & 23.2 & 1000 & 15.0 & 23.5 \\
\hline $\begin{array}{c}\text { Crushed stone } \\
\text { gravel mix }\end{array}$ & 21.0 & 3 & 41.5 & 22.5 \\
\hline
\end{tabular}

Schemes of calculating the stability of the slope according to Bishop for the system «base - subgrade - pavement» with cracks in the pavement (on the outer track) and without them are shown in Figure 5. The results of calculation are presented in Table 8. 
Table 8. The results of calculation of the stability of the system «base - subgrade - pavement».

\begin{tabular}{|c|c|c|c|c|}
\hline № & Radius, $\mathrm{m}$ & $\begin{array}{c}\text { Safety } \\
\text { factor, Fs }\end{array}$ & $\begin{array}{c}\text { Safety factor for an } \\
\text { earthquake measuring } 7 \\
\text { on the MCS scale, Fs }\end{array}$ & $\begin{array}{c}\text { Percentage of } \\
\text { change, } \%\end{array}$ \\
\hline Without a crack & $\begin{array}{l}9.32 \\
9.32\end{array}$ & 1.27 & 1.24 & -1 \\
\hline With a crack & $\begin{array}{c}9.18 \\
12,62\end{array}$ & 1.27 & 1.24 & -1 \\
\hline
\end{tabular}

Note: Radius in the numerator - without an earthquake; radius in the denominator - with an earthquake measuring 7 on the MCS scale

As can be seen from the data presented in Figure 7, the stability of the embankment slopes at a calculated uniformly distributed load $\mathrm{P}=5 \mathrm{kN} / \mathrm{m}^{2}$ practically does not change and does not depend on the presence (absence) of defects in the pavement.

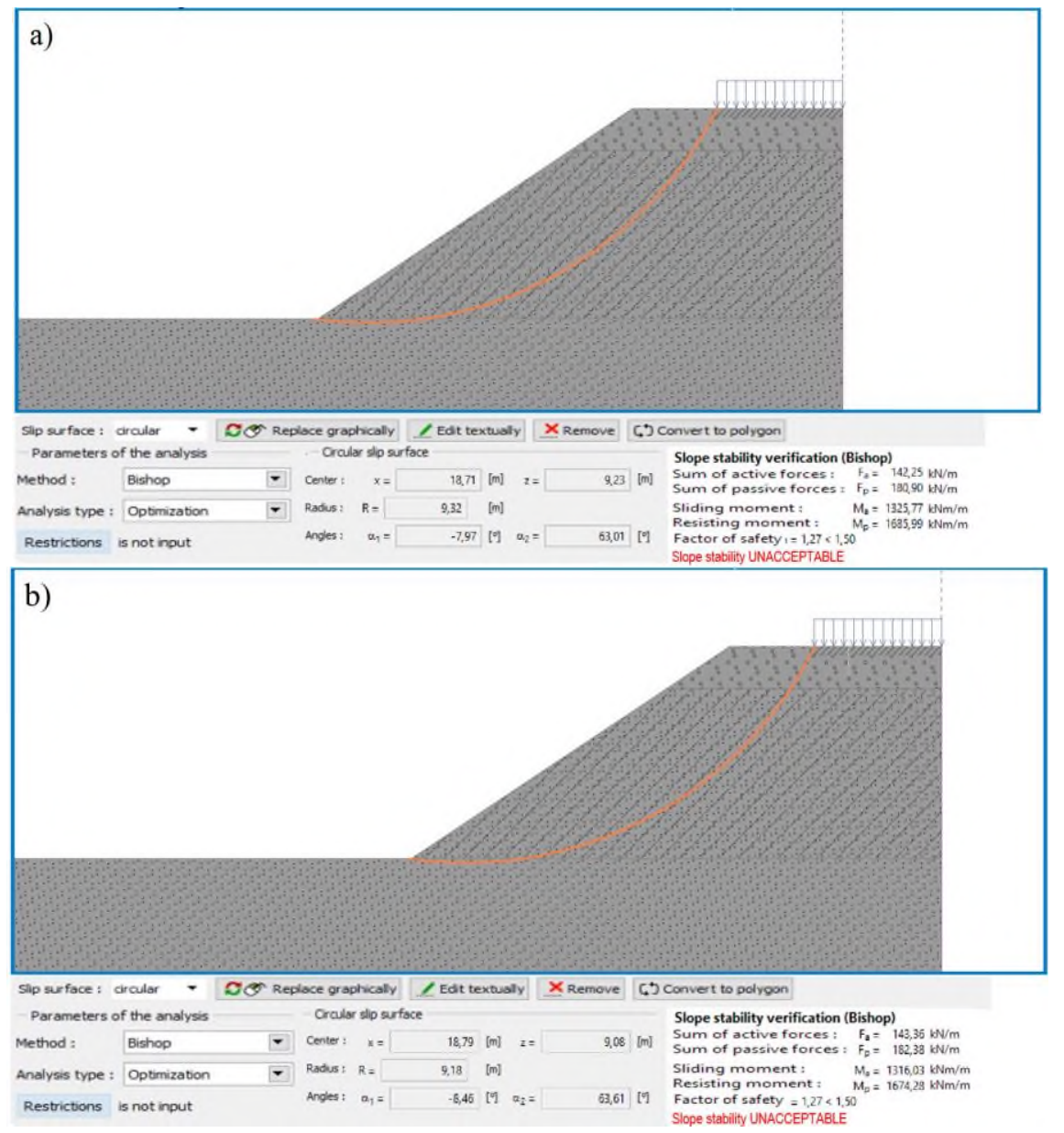

$\mathrm{a}$ - without defects in pavement; $\mathrm{b}$ - with a through crack in pavement

Fig. 5. The results of calculation of the stability of the system «base - subgrade - pavement».

In addition, the stability of the system was calculated for an earthquake measuring 7 on the MCS scale with factor of horizontal acceleration $\mathrm{Kh}=0.0150$ and factor of vertical acceleration $\mathrm{Kv}=0.005$. Schemes of calculating the stability of the slope according to 
Bishop for the system «base - subgrade - pavement» with cracks in the pavement and without them are shown in Figure 6. The results of calculation are presented in Table 8.
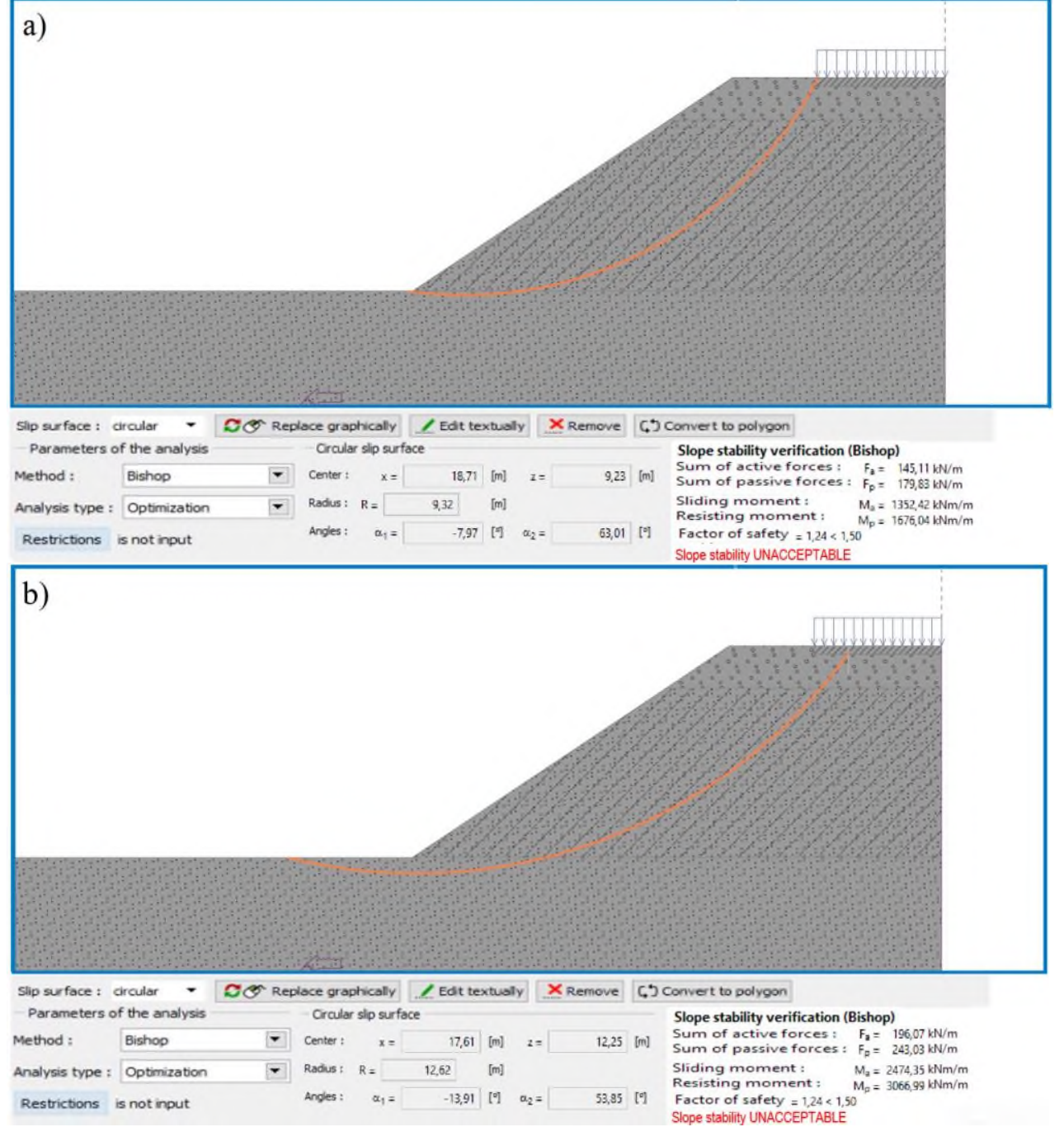

$\mathrm{a}$ - without defects in pavement; $\mathrm{b}$ - with a through crack in pavement

Fig. 6. The results of calculation of the stability of the system «base - subgrade - pavement» with an earthquake measuring 7 on the MCS scale.

As can be seen from the data presented in Table 8 and Figure 6 , the stability of the embankment slopes at a calculated uniformly distributed load $\mathrm{P}=5 \mathrm{kN} / \mathrm{m}^{2}$ and the presence (absence) of an earthquake measuring 7 on the MCS scale practically does not change for the system «base - subgrade - pavement» without defects in pavement. However, if there is a through crack in the pavement (40 cm deep), located on the outer track ( $1 \mathrm{~m}$ from the edge of pavement), the critical (optimal) sliding surface shifts from the edge of the carriageway to the location of the crack. This fact makes it potentially dangerous for vehicles to move or park on road sections with defects during earthquakes, since the destruction (sliding) of the embankment slopes is possible directly under the vehicle.

The construction solutions to improve the stability of slopes presented in Tables 5 and 6 are also well suited for strengthening the system «base - subgrade - pavement», regardless 
of the presence (absence) of defects in pavement and allow providing a safety factor for strengthening with anchors of at least Fs $=1.55$ and for strengthening with geosynthetic materials of at least $\mathrm{Fs}=1.68$.

\section{Discussion}

The results of the study correlate with the results of studies by Russian and foreign authors and do not contradict the existing theories and models of embankment slope stability.

Obtaining the results is of great practical importance and can be applied at the construction sites of highways in the areas of permafrost. In addition, the results of the study can be used to improve the "subgrade - pavement" system and to develop new ways to strengthen the embankment slopes.

\section{Conclusion}

The issues of assessing the stability of embankments on weak base are always relevant for road construction. The use of methods of mathematical modeling allows to consider a variety of factors at the design stage and to exclude the most common situations that affect the stability of the system «base - subgrade - pavement».

The assessment of the stability of the slopes of the systems «base - subgrade» and «base - subgrade - pavement» showed that it is necessary to provide measures for the comprehensive strengthening of slopes using anchor systems or geosynthetic materials for high embankments ( $5 \mathrm{~m}$ and more), located on weak thawed soils.

Reinforcement is the most effective way to strengthen slopes and increase the stability of embankments on weak base. Reinforced materials and soils have better physical and mechanical characteristics than unreinforced ones. The use of reinforcing structures and materials in the construction of the subgrade increases the service life and significantly increases the reliability of the embankment both under standard operating conditions and medium level of seismic activity.

The studies was supported by the grant of the President of the Russian Federation, contract No. 07515-2020-286 (internal number MK-511.2020.8).

\section{References}

1. A.F. Revuzhenko, Mechanics of Elasto-Plastic Media and Nonstandard Analysis (Novosibirsk State University Publ, 2000)

2. H. Huang Yand, Stability analysis of earth slopes (Stroyizdat Publ, 1988)

3. C.S. Desai, Some aspects of constitute models for geologic media. Third International Conference of Numerical Methods in Geomechanics, Aachen 2-6 April, 299-308 (1979)

4. N.I. Gorshkov, M.A. Krasnov, A.D. Lovtsov, V.S. Fedorova, Analysis and evaluation of the stress-strain state of the "Steel corrugated pipe (SCP) - foundation - backfill" system based on FEM, Bulletin of Civil Engineers 3, 152-160 (2019)

5. A.P. Kuleshov, V.V. Pendin, Influence of the method for determining soil properties in numerical calculations of deformations, Bulletin of the Tomsk Polytechnic University, Geo Assets Engineering 328 (12), 63-74 (2017)

6. M.M. Mirsaidov, E.S. Toshmatov, Spatial stress state and dynamic characteristics of earth dams, Magazine of Civil Engineering 89 (5), 3-15 (2019) 
7. I. Bellezza, L. Caferri, M. Di Sante, E. Fratalocchi, \& F. Mazzieri, Elastic-plastic analysis of passive rigid piles in coehesionless soils, 19th International Conference on Soil Mechanics and Geotechnical Engineering, 2723-2726 (2017)

8. D. Deng, L. Li, L. Zhao, Stability Analysis of a Layered Slope with Failure Mechanism of a Composite Slip Surface, International Journal of Geomechanics 19(6), 04019050 (2017)

9. S.A. Kudryavtsev, T.Iu. Valtseva, E.D. Goncharova, The development of structures for strengthening of sliding slopes from highway "Amur" with using of modern geosynthetic materials, PNRPU Bulletin. Construction and Architecture 7 (4), 111-122 (2016)

10. T.V. Maltseva, Mathematical theory of water-saturated soil (Vector Book Publ, 240, 2012)

11. Y.Balashova, V. Demianenko, N. Tkach, \& H.Karasev, Ensuring the sustainability of the motorway subgrade in the zones of underground mining operations, E3S Web of Conferences 123, 01041 (2019)

12. Y. Zhang, Z. Qu, L. Yang, Analysis and Influence of Salt Content on Stability of Saline Soil Subgrade Slope, IOP Conference Series: Earth and Environmental Science 384 (1), 012072 (2019)

13. S.P. Varlamov, The soil thermal properties in the impact zone of railway in Central Yakutia, Bulletin of North-Easter Federal University. Series "Earth sciences" 1(13), 3647 (2019)

14. R.V. Zhang, Geocryological monitoring of low-and medium-head embankment dams on permafrost in view of climatic change, Modern Problems of Science and Education 6, 94 (2013)

15. L.E. Khaliulina, On permanent soils in road construction, Scientific Research 3(22), 10-12 (2018)

16. E.M. De Guzman, M. Alfaro, Settlement of embankments on peat foundations: Two case studies, 19th International Conference on Soil Mechanics and Geotechnical Engineering, 1349-1352 (2017)

17. O. Zhang, G. Yang, Y. Zhao, H. Lu, L. Hou, Parametric Influences of Stability and Settlement Pattern of Embankment on Slope Foundation, IOP Conference Series: Earth and Environmental Science 560(1), 012047 (2020)

18. I.K. Fomenko, Current trends in slope stability calculations, Engineering Geology 6, 44-53 (2012)

19. J.M. Duncan, P. Dunlop, Development of Failure around Excavated Slopes, J. of Soil Mechanics and Foundation Division, ASCE 96(SM2), 471-494 (1970)

20. H. Mei, W. Leng, R. Nie, R. Tu, Y. Li, J. Dong, Experimental research on the dynamic response characteristics of the transition subgrade induced by heavy-haul train passage, Proceedings of the Institution of Mechanical Engineers, Part F: Journal of Rail and Rapid Transit 233(9), 974-987 (2019)

21. Z. Sun, Z. Zhao, J. Zhang, K. Yuan, X. Xue, Study on Deformation Evolution of Loess Cutting Slope in Expressway, IOP Conference Series: Materials Science and Engineering 392(6), 062006 (2018)

22. E.S. Kiryanova, V.V. Konyushkov, On the influence of the strength characteristics of the soil on the stability of an unreinforced and reinforced embankment, Materials of the Scientific and Practical Conference Composite materials in the construction of transport infrastructure facilities, 16-21 (2018) 